\title{
THOMAS WILLIS AND THE FEVERS LITERATURE OF THE SEVENTEENTH CENTURY
}

\author{
by
}

\author{
DON G. BATES*
}

WE NEED not take literally the "common Adagy Nemo sine febri moritur," even for seventeenth-century England. ${ }^{1}$ Nor is it likely that Fevers put "a period to the lives of most men". ${ }^{2}$ Nevertheless, the prevalence and importance of this "sad, comfortless, truculent disease" in those times cannot be doubted. Thomas Willis thought that Fevers had accounted for about a third of the deaths of mankind up to his day, and his contemporary and compatriot, if not his friend, Thomas Sydenham, guessed that twothirds of deaths which were not due to violence were the result of that "army of pestiferous diseases", Fevers. ${ }^{3}$

These estimates are, of course, based almost entirely on impressions. ${ }^{4}$ But such impressions form the subject of this paper, for it is the contemporary Fevers literature upon which I wish to focus attention, the literature covering little more than a century following the death of the influential Jean Fernel in 1558.

In what follows, I shall poke around in, rather than survey, the site in which this literature rests, trying to stake out, however disjointedly and incompletely, something of the intellectual, social, and natural setting in which it was produced. In keeping with the spirit of this volume, this is no more than an exploratory essay of a vast territory and, even so, to make it manageable, I have restricted myself largely to

*Don G. Bates, M.D., Ph.D., Department of Humanities and Social Studies in Medicine, McGill University, Montreal, Canada. This research was supported, in part, by grants from the Social Sciences and Humanities Research Council of Canada and the Hannah Institute for the History of Medicine.

${ }^{1}$ George Starkey, Natures explication and Helmont's vindication .... London, 1657, p. 253. Starkey himself thought the expression "more subtle then true".

${ }^{2}$ Charles Goodall, The Colledge of Physicians vindicated ..., London, 1676, p. 32. I shall use "Fevers", capitalized, when it refers to various febrile diseases in the sense still meant today by terms like typhoid fever, yellow fever, scarlet fever, lassa fever, etc. For the physiological process of "fever". the term will not be capitalized. These two senses of the term existed in the literature of the period, indeed long before it.

${ }^{3}$ Starkey, op. cit., note 1 above, p. 253; Thomas Willis, Diatribae duae medicophilosophicae quarum prior agit de fermentatione. ... Altera de febribus, sive de motu earundem in sanguine animalium ...., London, 1659, sig. $\mathrm{H}_{3}{ }^{\prime}$; G. A. Greenhill (editor), Thomae Sidenham. M.D.. Opera omnia, London, Sydenham Society, 1846; "Observationes medicae", VI:7:11.

"In an earlier manuscript (1670), Sydenham had thought one-half rather then two-thirds. (The Vaillant Manuscript notebook of Sydenham's observations from 1669 to 1674, in the Library of the Royal College of Physicians, London, f. $32^{v}$.) On the other hand, in one instance at least, Sydenham indicated that he was making use of the Bills of Mortality (ibid., f. $17^{r}$ ). Willis's one-third could possibly have been influenced more by tradition than by clinical impressions. Apparently estimates of a one-third loss of mankind in the Black Death were a commonplace of medieval chroniclers, borrowing from St. John`s figure for mortality from plague in Revelation (Barbara W. Tuchman, $A$ distant mirror: the calamitous fourteenth century, London, Macmillan, 1979, p. 94). 
England and to the work of Thomas Willis as a particular case study.

At the outset, one thing is certain: the material under study is central in the seventeenth-century medical landscape. Few major medical authors failed to consider Fevers and fever, either in monographic form or within discussions about other things. ${ }^{5}$ Jean Fernel himself devoted the fourth book of his 'Pathologia' to them, as well as a separate treatise on their treatment, and Iain Lonie has given us some detailed insight into the formal Fevers literature of Fernel's contemporaries. ${ }^{6}$ Similarly prominent attention to the subject, later in the sixteenth century, was paid by Augenius and Platter, to single out only the two authors whom we shall have occasion to refer to again. ${ }^{7}$ It is curious, and perhaps significant, that in his voluminous writings Paracelsus devoted no protracted work to the subject although it was mentioned sporadically throughout his publications and manuscripts. The same is true of one of his most influential followers, Petrus Severinus of Denmark . ${ }^{8}$ Daniel Sennert's very large tome on Fevers of 1619 is itself a good guide to the significant earlier literature. While in actual volume, Helmont's tract on fevers is not large relative to his works as a whole, it is a primary source for his ideas about disease in general. By the end of the period in question, Willis and Sylvius had begun their publishing careers with works on Fevers, and Sydenham, shortly after, initiated two decades of works dominated by his interest in these diseases. ${ }^{9}$

One reason for the prominence of Fevers in this medical literature is obvious: Fevers were salient in the experience of everyone. They were ubiquitous and their visitations often dramatic. Confronted with their dominating presence, one would expect medical

\footnotetext{
${ }^{3}$ Even for someone like William Harvey, working on a topic like the circulation of the blood, the matter of fever was important. See Jerome J. Bylebyl, 'The medical side of Harvey's discovery: the normal and the abnormal, in J. J. Bylebyl (editor), William Harvey and his age, Baltimore, Md., Johns Hopkins University Press, 1979, pp. 28-102, see pp. 54f., 86f.

'According to Sherrington's bibliography, Fernel's 'Pathologia' appeared for the first time in his Medicina of 1554, and the Febrium curandarum methodus generalis only posthumously, in 1577, although the latter was apparently written in 1557 or 1558. See Charles Sherrington. The endeavour of Jean Fernel, Cambridge University Press, 1946, pp. 136, 196. I. Lonie. 'Fever pathology in the sixteenth century: tradition and innovation', in W. F. Bynum and V. Nutton (editors). Theories of fever from antiquity to the enlightenment, (Medical History Supplement No. 1), 1981, pp. 19-44.

${ }^{7}$ Horatius Augenius, De febribus, febrium signis, siniptomatibus, et prognostico libri septem ...., Franfurt, 1605. The work was actually finished c. 1572. Felix Plater [Platter], De febribus ..., Frankfurt, 1597.

'See Martin Müller, Registerband zu Sudhoffs Paracelsus-Gesamtausgabe, Nova acta paracelsica, Supplementum, Einsiedeln, 1960, under the term "fieber" for the many references throughout the work of Paracelsus. The references are to the Sudhoff edition of Paracelsus, sämtliche Werke, Munich and Berlin, various publishers and dates. See esp. vol. 3. (1930), pp. 449-453; vol. 5. (1931), pp. 1-182 passim; vol. 8, (1924), pp. 371-395; and vol. 9, (1925), pp. 541-638. Petrus Severinus, Idea medicinae philosophicae. fundamenta continens totius doctrinae Paracelsicae. Hippocraticae et Galenicae. Basle, 1571.

- Daniel Sennert. De febribus, libri IV. Wittenberg, 1619; J. B. Van Helmont, Febrium doctrina inaudita, Antwerp, 1642; Willis, op. cit., note 3 above. According to the bibliography prepared by E. D. Baumann, in his François dele Boe, S. $\%$ vius, Leiden, E. J. Brill, 1949, p. 240. Sylvius wrote several works in anatomy and physiology, 1658 to 1661 , before writing his first disputations on Fevers in 1661 . His work on Fevers of 1670 (item 14b of the bibliography), was the more commonly cited work, however. Thomas Sydenham, Methodus curandi febres, .... London, 1666. Although called Observationes médicae morborum acutorum historiam et curationem. Sydenham's magnum opus of 1676 was essentially on Fevers, as he himself acknowledged, (op. cit., note 3 above, VI:7:10). The last work published during his lifetime was his Schedula monitoria de novae febris ingressu, London, 1686.
} 


\section{Thomas Willis and the fevers literature of the seventeenth century}

authors to reflect this in their writings. Moreover, given the era of brilliant descriptive biology, with its highly successful effort to observe and describe carefully such things as human anatomy and plant morphology, one could reasonably expect that the subject of Fevers might also receive such care and attention.

But one striking thing about the Fevers literature, from Fernel to Willis, noticeable even on superficial acquaintance, is that its relationship to experience is indirect, clearly mixed with and mediated by other concerns, and that, however much Vesalian example and Baconian inspiration were motivating natural historians in other fields, authors on Fevers did not, by and large, make use of that approach. True, throughout the period various authors mentioned cases or epidemics of which they had had experience, and, very early on, Guillaume de Baillou had attempted to chronicle the disease events in his area from 1570 to $1579 .{ }^{10}$ But the former were invariably to illustrate or support a point, and Baillou's accounts were self-conscious efforts to imitate the Hippocratic Epidemics. Even the more extensive descriptions by Willis of particular epidemics which he had directly experienced were intended to support an $a$ priori thesis. ${ }^{11}$ It was not without reason, then, that, as late as 1676, Sydenham complained about such practices and, invoking the name of Bacon, called once again for the sort of disinterested descriptive science that was being practised by botanists. ${ }^{12}$

What part natural events may have played, and what the new natural philosophies clearly did play, in the formation of this literature, will be considered later. It seems appropriate, however, to consider first what was surely the greatest influence - tradition. What was written between 1558 and 1676 was shaped, in fundamental ways; by what had been written before.

As Lonie has shown us, Galen's extensive writings on Fevers were still being picked over, sifted, shuffled, and reshaped by Galenists of the late Renaissance. Nor did the Galenic doctrine of Fevers die with the sixteenth century but continued to thrive through the entire period under study. In England, Fernel enjoyed considerable influence and in France his 'Pathologia' which was re-issued thirty-six times in little over a century, was still in use in Paris in $1660 .{ }^{13}$ The Institutiones of Rivière, containing a thoroughly Galenic treatise on Fevers, was a favourite of the examiners of the

\footnotetext{
${ }^{10}$ Gulielmus Ballonius, Epidemiorum et ephemeridum libri duo, studio et opera M. Iacobi Thevart . . in lucem primum editi, Paris, 1640.

"See the last chapter, on epidemic fevers, in Willis, op. cit., note 3 above. Elsewhere, I have discussed the descriptiveness of another of Willis's accounts ('Thomas Willis and the epidemic fever of 1661: a commentary', Bull. Hist. Med., 1965, 39: 393-413). See also, H. W[hitmore], Febris anonala: or the new disease ..., London, 1659, for an example of a "description" of a particular epidemic in a particular place which is so couched in traditional terminology as to lack all semblance, to us, of descriptiveness.

12 Sydenham, op. cit., note 3 above, preface to the 3 rd ed., sect. 9; sect. 5 . I have deliberately used a cutoff date for this study (1676) to eliminate any extended consideration of Sydenham, whose major work on Fevers appeared in that year. True, he had published his earliest two editions on Fevers in 1666 and 1668 but, apart from a partially completed description of smallpox, these early works did not display the interest in "natural histories" which would become programmatic in 1676. As I am just completing a monograph on Sydenham's formative years I have arbitrarily decided to leave the present account as a background to that study. Sydenham's work, I believe, constitutes something of a turning-point in the trends being discussed here.

${ }^{13}$ Christopher Hill, Intellectual origins of the English Revolution, Oxford, Clarendon Press, 1965, p. 36, fn. 1: Sherrington, op. cit., note 6 above, p. 103.
} 
Royal College of Physicians of London in 1662. A very helpful didactic digest of the ancient doctrine of Fevers, written originally in 1620, it was translated into English in 1657. In that same year, a defence of "Hippocratic" medicine against hermeticism was published in Lyons, and the 'Tractatus de febribus' contained in it is handled in a. form entirely familiar to Renaissance Galenism. ${ }^{14}$ A final example, from the many that could be adduced, a work published at Padua in 1668 on diseases of women, has a section on febrile diseases which is pure Galenism. A copy of this particular work was bought by John Locke, but he never bound it or indeed even cut the pages. Perhaps his neglect reflected his disenchantment with its conservatism. ${ }^{15}$

But the impact of tradition on the seventeenth-century literature did not amount just to the perpetuation of texts expounding the Galenic doctrine of Fevers. The impress of the past can also be found in the apparently avant-garde work of a man like Thomas Willis, especially seen if his treatise on the subject is compared with that of Jean Fernel. ${ }^{16}$

Lonie has already shown us that, despite Fernel's departures from medieval Galenism, he remained, in the main, a faithful transmitter of Galenic doctrine on the subject of Fevers. ${ }^{17}$ When his work is compared with that of Willis, a striking similarity can be found in the basic framework within which each author considered his subject. For both authors, the starting-point for a true fever is in the area of the heart. ${ }^{18}$ For both, the large category of putrid Fevers arises from processes which are basically a miscarriage of digestion and assimilation. Although considered in a different order, the taxonomy of Fevers is essentially the same. Both divided them, for example, into three main groups, simple, putrid, and pestilent (or, in Willis's terminology, "malignant"). ${ }^{19}$ Many of the same signs, symptoms, and epidemiological

\footnotetext{
14 Robert G. Frank Jr., 'The John Ward diaries: mirror of seventeenth century science and medicine', $J$. Hist. Med., 1974, 29: 147-179, see p. 161. Rivière's work was translated by Nicolas Culpeper, et al., as Lazarus Riverius, The practice of physick in 17 several books . .., London, 1655. Book 17 is on Fevers. We cannot say, of course, that that particular book was used by the examiners. Brice Bauderon, The expert physician. learnedly treating of all agues and feavers . .., translated into English by B. W., London, 1657; Gabriel Fontanus, De veritate hippocraticae medicinae . . . seu medicina antihermetica. Lyons, 1657.

${ }^{15}$ Raimondo Giovanni Forti, De febribus et morbis mulierum facile cognoscendis atque curandis, Padua, 1668. See John Harrison and Peter Laslett, The library of John Locke, Oxford Bibliographical Society: Oxford University Press, 1965, no. 1157. Locke's copy is in the Locke Room of the Bodleian Library, Oxford.

${ }^{16}$ Since Willis died on 11 November 1675, the deaths of Willis and Fernel bracket the period under study. Both men died of Fevers, as did Fernel's wife. (Sherrington, op. cit., note 6 above, p. 209; Thomas Willis, Pharmaceutice rationalis, London, 1679, sig. $\left[\mathrm{A}_{4}^{\mathrm{V}}\right]$.) Willis"s father died of "camp-Fever" during the Civil War (ibid., sig. $\left[\mathrm{A}_{3}{ }^{\mathrm{V}}\right]$ ). For a précis of Willis's De febribus as it first appeared in 1659, see Robert G. Frank Jr., Harvey and the Oxford physiologists. A study of scientific ideas, Berkeley, Los Angeles, and London, University of California Press, 1980, pp. 167-169.

${ }^{17}$ Lonie, op. cit., note 6 above, p. 33f. A prominent Paracelsian certainly saw Fernel as official spokesman for Galenism (Severinus, op. cit., note 8 above, p. 19 and passim).

18 Ioannus Fernelius, Universa medicina, Frankfurt, 1577. 'Pathologia', p. 172f.: Willis, op. cit., note 3 above, pp. 18ff., 89, and passim. See Frank, op. cit., note 16 above, p. $168 \mathrm{f}$. where, among other things, he points out Willis's "conservatism" in his unwitting reversion to the kind of Galenic preoccupation with the heart opposed by Harvey.

${ }^{19}$ Sub-groups are also much the same. Compare Fernel, op. cit., note 18 above, p. 173, with Willis, op. cit., note 3 above, table of contents and p. 64f. The similarities are partially obscured by Willis's consideration of intermittent Fevers first, followed by continued ones. But the former are engendered by the same process as continued putrid Fevers (ibid., p. 109), so that Willis could have subsumed them under the general category of putrid Fevers as Fernel had done. Lonie, op. cit., note 6 above, p. 27f., has mentioned
} 


\section{Thomas Willis and the fevers literature of the seventeenth century}

characteristics informed the clinical differentiation of the two authors. ${ }^{20}$ If Fernel were to have looked at the table of contents of Willis's book it would have appeared entirely familiar to him since it varies no more from his than did those of some of his contemporaries. $^{21}$

But there are even more important similarities. While it is true that, for Fernel, the essence of fever was preternatural heat whereas for Willis it was an inordinate motion of the blood, these superficial distinctions are transcended by the fact that, for both men, fever was still the central feature of Fevers, providing not only the unity and boundary lines of that category of diseases but also the basic physiological process, the variations of which account for the major variations in the Fevers themselves. ${ }^{22}$ Anatomical variations, in our sense of gross and microscopic morbid changes in the body parts, were decidedly secondary and still largely speculative in Willis's work as they were in Fernel's. ${ }^{23}$ Not only is there scant hint of the approach of anatomical pathology of the nineteenth century, or that of external aetiology engendered by the later germ theory, there is a clear implication that neither of these approaches would be as fruitful as coming to understand bodily processes. In this respect, Willis was far closer to Galen than he was to Osler. ${ }^{24}$

this change in seventeenth-century authors.

${ }^{20}$ For example, in Willis, op. cit., note 3 above, p. 88f., he takes the "phenomena" of putrid fever more or less for granted and orients his discourse entirely to fitting them to his theory of Fevers. By the third edition he has added a more complete (and standard) description of the signs and symptoms and explains that he has done so so that he can explain "upon what causes each species of them [i.e., the symptoms] depends and by what operation they are usually excited in our body" (Thomas Willis, Diatribae duae, 3rd ed., London, 1662, p. 179).

${ }^{21}$ Apart from dealing with intermittent Fevers first, Willis also differs from Fernel in having a separate chapter on smallpox and measles. But this was also true of Fernel's late contemporary, Augenius, op. cit., note 7 above, books IX and X. More will be said of this later. Altogether, the precise arrangement of the Fevers varies considerably, based on the author's own views about ordering or arranging their exposition. But the names appear to remain quite consistent or to be translatable into a common taxonomy. But this is impressionistic. It would be very helpful to have a carefully worked-out history of the taxonomy of Fevers for the sixteenth and seventeenth centuries. Compare, for example, the schema delineated by Fernel with those of Augenius (various tables scattered through the first six books), Platter, (op. cit., note 7 above, at the front of his work), Joannes Heurnius, De febribus, Leyden, 1598, p. 9f.; Edward Edwards, The cure of all sorts of fevers ..., London, 1638, (many charts); Bauderon, op. cit., note 14 above, Ch. II, 'Differences of Fevers', and Willis's table of contents.

${ }^{22}$ Fernel, op. cit., note 18 above, p. 172f.; Willis, op. cit., note 3 above, p. 25, for the definition of fever; pp. 64-66 for the continued Fevers, pp. 26-33 for the intermittents.

${ }^{23}$ Indeed, the postulated physiological processes involved in the notion of fever were also largely speculative. For that matter, so were notions of body heat (Everett Mendelsohn, The changing nature of physiological explanation in the seventeenth century', in Alexandre Koyré, L'aventure de la science. Mélanges publiés à l'occasion de son $70^{e}$ anniversaire, Paris, Hermann, 1964, pp. 367-386, see p. 386). This may account for the fact that post-Vesalian anatomy and post-Harveian physiology did not force fundamental changes in the traditional doctrine of Fevers, although Willis proclaimed that his doctrine was based on the discovery of the blood's circulation (Willis, op. cit., note 3 above, sig. $\mathrm{H}_{1}{ }^{\mathrm{v}}-\mathrm{H}_{2}{ }^{\mathrm{r}}$ ), which he did make use of from time to time, e.g., pp. 15 and 36. In the first of these examples Willis was enlisting the circulation in his efforts to involve the nervous system to account for some of the phenomena of Fevers, and in the second example, the circulation accounts for the generalized nature of fever. On this subject, and on the variety of meanings lent to the term "anatomy" by Willis and his contemporaries, see Audrey B. Davis, Circulation physiology and medical chemistry in England 1650-1680, Lawrence, Kansas, Coronado Press, 1973, pp. 134-141. That Willis's work on Fevers is not anatomical and not faithful to his putative inspiration has been noted by Frank, op. cit., note 16 above, p. 169.

${ }^{24}$ In Sir William Osler's textbook, The principles and practice of medicine, New York, Appleton, 1892, the category is 'Specific infectious diseases', not 'Fevers'. 


\section{Don G. Bates}

But the traditionalism apparent to us, living on this side of Osler's time, was by no means as obvious in Willis's day. On the contrary, his doctrine of Fevers was so "modern" as to make it controversial. It provoked vigorous opposition from the conservative Edmund Meara; was part of the evidence adduced by Charles Goodall to defend the modernity of the College of Physicians; and generated a good deal of comment by several continental authors. ${ }^{25}$ Clearly Willis did not write his tract on Fevers merely to perpetuate or defend tradition. On the other hand, as will be noted later, if he had wanted to depart radically from Galenism, there were theories and ideas ready to hand.

But before pursuing the conservative dimension of his work further, it will be useful to look at what it was that made his doctrine appear "modern". This can be highlighted by again comparing what he wrote with that of Fernel.

The most striking difference is in the basic imagery evoked by their respective descriptions of internal febrile processes. In the case of Fernel, that imagery is, for lack of a better term, "biocentric" in the sense that the substances and processes invoked remain within and are peculiar to the domain of the living or the formerly living: food, humours, body parts, excrements, digestion, fermentation, decay, putrefaction, and rotting. Indeed, for all the refinements of academic Renaissance Galenism, the doctrine of Fevers still gives off (as probably many victims of those diseases did), a faint odour of the charnel-house and the refuse heap. ${ }^{26}$ On the eve of Willis's work, many authors were still writing influential books within that basic idiom, ${ }^{27}$ which remained meaningful and defensible, for example, to someone like William Harvey. ${ }^{28}$

But not to Willis. Into his old bottles he was pouring new wine. Cooking was giving way to chemistry; the shufflings of inanimate atoms were conjuring up the laboratory rather than the kitchen; Cartesian-like, the life-domain, the "biocentric", was being breached by that which had never lived. ${ }^{29}$ In more general terms, Willis's

\footnotetext{
${ }^{25}$ Edmundo de Meara, Examen diatribae Thomae Willisii de febribus, Amsterdam, 1667 (who in turn prompted a defence by Willis's associate Richard Lower which is summarized and discussed by Frank, op. cit., note 16 above, pp. 188-192); Goodall, op. cit., note 2 above, p. 49f. For continental responses, see various cross-references under Willis entry in the General catalogue of printed books 101955 of the British Museum (British Library).

${ }^{26}$ This "life-domain" and the biocentric imagery it invokes includes its own form of heat, "innate", and its own vital flame so that, even where an analogy is made with fire (e.g., Fernel, op. cit., note 18 above, p. 176), this distinction holds good. The important thing is that explanations having to do with the materials and processes of this domain are not typically reduced to or expressed in terms of the universe of the physical and inanimate.

${ }^{27} \mathrm{~A}$ case in point is Francis Glisson whose thought in this regard is analysed by Theodore M. Brown, 'Physiology and the mechanical philosophy in mid-seventeenth century England', Bull. Hist. Med., 1977, 51: 25-54, see pp. 38-44; and by Owsei Temkin. 'The classical roots of Glisson's doctrine of irritation". ibid., 1964, 38: 297-328. Temkin's concluding remarks (pp. 324-328) are germane to this entire section of my discussion. With specific reference to fever, see Theodore M. Brown. 'The College of Physicians and the acceptance of iatromechanism in England, 1665-1695, ibid., 1970, 44: 12-30, see p. 14.

${ }^{28}$ Brown, (1977), op. cit., note 27 above, pp. 36, 43, 45; Frank, op. cit., note 16 above, p. $18 f$.

${ }^{29}$ For Willis's Cartesianism, see Brown, (1977), op. cit., note 27 above, pp. 46-50; Frank, op. cit., note 16 above, p. 168. Meara hinted that Willis got his ideas for his work on Fevers from the Cartesian, Cornelis van Hooghelande, Meara, op. cit., note 25 above, e.g., p. 77. Willis`s mechanism is discussed by Brown, (1970), op. cit., note 27 above, p. 20f. The most basic expression of this, of course, was the notion that the blood was made up not of humours but of the five "principles", spirit, sulphur, salt, water, and earth. That
} 


\section{Thomas Willis and the fevers literature of the seventeenth century}

treatise exchanged Aristotelian qualities, ancient humours, and Galenic physiology for Cartesian corpuscles, chemical constituents, and Harveian circulation. What separates Willis from Fernel, finally, is not a hundred years of observation and accumulated clinical experience with Fevers, but the new mental world being colonized by Harvey, Gassendi, Descartes, and Boyle. The difference is not the result of new knowledge, new discoveries, or new scientific methods stemming from the study of Fevers themselves, but rather a new vocabulary, a new set of doctrines borrowed from various contemporary currents in a new natural philosophy. ${ }^{\mathbf{3 0}}$

Yet even this process of translation was by no means complete, nor as radical a departure as it first seems. Take, for instance, the notion of fermentation, the central theme of Willis's treatise on Fevers and the subject of the tract that appeared with it. In the first place, his comparison of wine-making with bodily processes is as old as Galen. Even in the realm of Fevers, Rhazes compared the blood in smallpox to a fermenting process. Fernel, himself, at one point, implied that fermentation is one kind or grade of putrefaction. ${ }^{31}$ Moreover, Willis seems at times to use "effervescence" either as a synonym for fermentation, or at least as the heat-producing, bloodagitating part of the process and certainly as the essence of fever. This, too, is a term one encounters in the traditional literature, along with its apparent synonym of ebullition. ${ }^{32}$ Still further blurring occurs when one tries to distinguish Willis's "fermentation" from the classical notion of "putrefaction", as applied to Fevers. The latter, which traced its origins to Aristotle, was itself a complicated and not altogether clear notion which, however, did include heat production and the breakdown or conversion of one substance into another. Indeed, the similarity between classical putrefaction and Willis's modern fermentation was recognized by Glisson and, in the case of putrid Fevers, acknowledged by Willis himself. ${ }^{33}$ This is not to say that there

these were both chemical and atomistic is argued by Frank, op. cit., note 16 above, p. 165 f. Examples of his appeal to corpuscularian mechanism abound: the poisonous venom of plague is a confusion of atoms (Willis, op. cit., note 3 above, p. 146f.); the pus of buboes is created by the concoction of trapped blood which gives off its salt and sulphur particles (Thomas Willis, The London practice of physick or the whole practical part of physick contained in the works of Dr. Willis, English translation by Eugenius, London, 1685, p. 594); amulets work in a corpuscularian manner (ibid., p. 597).

${ }^{30}$ For a general discussion of this theme see Lester S. King. 'The transformation of Galenism', in A. G. Debus (editor), Medicine in seventeenth century England, Berkeley, Los Angeles, and London, University of California Press, 1974, pp. 7-31.

${ }^{31}$ Galen. On the natural faculties, trans. A. J. Brock, London, Heinemann, 1952, p. 209; Rhazes, $A$ treatise on the smallpox and measles, trans. W. A. Greenhill, London, Sydenham Society, 1847, p. $29 \mathrm{f}$. Fernel, op. cit., note 18 above, 'Therapeutices', pp. 111, 112. Willis repeatedly resorted to the simile of brewing (e.g., Willis, op. cit., note 3 above, pp. 29, 46), explicitly compared and contrasted fermentation in wine and in blood (ibid., p. 17f.), at the same time making clear that both were in fact forms of fermentation (ibid.).

32 Willis, ibid., pp. 25, 109; Augenius, op. cit., note 7 above, pp. 280f., 362; Platter, op. cit., note 7 above, p. 46. Fernel explained that effervescence was a heating-up of the blood, short of putridity or other taint, (Fernel, op. cit., note 18 above, p. 173). Willis's traditionalist contemporary, H. Whitmore, seems to have made ebullition a feature of fermentation, (op. cit., note 11 above, p. 41).

${ }^{33}$ A discussion of the Aristotelian doctrine, full of scholastic nuance, is offered by Augenius, op. cit., note 7 above, pp. 121-123. See also Fernel, op. cit., note 18 above, p. 175, where the basic transformation implied in putrefaction (if not the exact mechanism) is similar to Willis's fermentation. Glisson's comment is in his Tractatus de ventriculo et intestinis, London, 1677, p. 413f. For Willis's approval of maintaining the name "putrid" fever, see Willis, op. cit., note 3 above, p. 72 f. See also his 'De fermentatione', ibid., pp. 
was no difference, or that these differences are unimportant, but rather that, in a work like Willis's old and new can be intimately interwoven down to a fairly basic level of explanatory detail. ${ }^{34}$ The conservatism of Willis's transformation is even more profound. The reasonably thorough-going corpuscularianism of his concept of fermentation, for example, should not obscure the other, very traditional, explanatory devices to which he frequently resorted. To explain this, we must first return to Galenic tradition.

There, the "biocentric" materials and processes of traditional explanations, when acting in the living body, were supplemented by an invocation of vital and psychic faculties: living, thinking causes which added that something extra to transform the dead and motiveless foods into living, intentional flesh. ${ }^{35}$ One would expect a thoroughgoing corpuscular mechanism to eschew such explanations, ${ }^{36}$ but, in Willis's work, more than vestigial bits of the vital and the psychic remain. In some cases, it is true, such actions are being taken over by a semi-mechanized nervous system, as when he explained vomiting in Fevers not as the result of a purposeful ejection of noxious matter but as merely the convulsive activity of a very sensitive stomach. ${ }^{37}$ On the other hand, what is one to make of his statement that the paroxysms of intermittent Fevers become bad habits of a delinquent nature? ${ }^{38}$ Nowhere is this psychism of nature more often invoked than with respect to treatment and natural healing processes. Here, in the notions of crises and the healing power of nature, an inherent "wisdom of the body" is manifest again and again. ${ }^{39}$ Form and function are not invariably wedded by chemical and mechanical laws.

49-65, where he explains the putrefaction of bodies as a form of fermentation. It appears that, in classical doctrine, fermentation is subsumed under putrefaction; with Willis, the relationship is reversed.

${ }^{34}$ For detailed descriptions of Willis's notion of fermentation and how it compares with other contemporary "modern" accounts see Frank, op. cit., note 16 above, p. 165f., and Davis, op. cit., note 23 above, pp. 65-92. That Willis was later obliged to drop the notion of fermentation of the blood, in favour of "enkindling" or "accensio", is discussed by Frank, op. cit., note 16 above, p. 236.

${ }^{33}$ For example, see Sherrington, op. cit., note 6 above, p. 71, for a discussion of now Fernel saw mind as immanent in organs like the stomach. These vital and psychic faculties, as long as they were believed, seem to have obviated the need for mechanistic explanations of phenomena generated at the sub-ocular level. See Frank, op. cit., note 16 above, p. 9. Frank`s label for this classical physiology, "the anatomical tradition". strikes me as infelicitous. It is not merely the size of the parts, (organ-sized vs. corpuscular) that distinguish this "biocentric" mode of thinking from the Cartesian corpuscularianism used by Willis. In today"s terminology "biocentric" is roughly equivalent with that we mean by "organic", but this term introduces connotations which are misleading as well as anachronistic.

${ }^{36}$ See, for example, George Ent's explicit renunciation of such causes as discussed by Brown, (1977), op. cit., note 27 above, p. $28 f$.

37 "Pars valde nervosa", (Willis, op. cit., note 3 above, p. 36). An explanation of convulsions in semimechanical terms is offered on p. 94f. They are "semi-mechanical" because, while inflating and distending the nerves, on the one hand, the spirits nevertheless become "exhausted" and "weakened" on the other, "quia Spiritus plurimum exhausti, et debilitati non satis inflant" (ibid., p. 94f.).

${ }^{38}$ Ibid., p. 40f. Though the surrounding text undergoes changes in subsequent editions, this curious passage survives into his final edition ( $D r$. Willis's practice of physick, London, 1684, 'Or fevers', p. 62).

${ }^{39}$ When the fever is at its height, the motion of nature must be diligently watched whether or not a crisis is to be accomplished (Willis, op. cit., note 3 above, p. 112, and again p. 114). As if in a quarrel called to trial, a judgment is made between nature and the disease, giving rise to a crisis (ibid.. p. 79). However. these crises are not controlled by the influence of moon and stars, but by the [mechanical] "congestion and turgescence of the adust matter" (ibid., p. 80). In the treatment of most illnesses, the physician serves as midwife to nature who does the main work (ibid., p. 155). Nature ought not to be diverted from her work by the 


\section{Thomas Willis and the fevers literature of the seventeenth century}

This comparison of Fernel (or Galenism) and Willis on Fevers, has been intended to demonstrate two things. First, however much Willis may have intended, by his two treatises on fermentation and Fevers, to declare a new approach to the understanding of those diseases, his work was profoundly influenced by a still robust traditional system of beliefs, about human physiology in particular, and natural philosophy in general. Second, to the extent that he did embark on a new path, the direction he was taking was entirely dictated by trends in other areas of thought and investigation. His work was, intellectually, derivative, its sources being tradition and new fields of natural studies.

I have concentrated on Willis's work because I believe that its very transitional and derivative character is typical of much of the Fevers literature of the seventeenth century, as far as its intellectual content is concerned. Certainly this is true of his continental contemporary, Franciscus de Le Boë (Sylvius). It also seems to apply to the writings of Daniel Sennert, who wrote a major work on the subject midway between those of Fernel and Willis. In Sennert's case, the link with tradition is even stronger, "modern" ideas (Paracelsian chemistry and atomism rather than Cartesian corpuscularianism) even more tentative and the basic effort one of reconciliation rather than fundamental reform. ${ }^{40}$

A further benefit of examining Willis's De febribus, is that its striking conservatism throws into sharp relief the radical departure of Paracelsus, and particularly of Van Helmont, whose work contains a truly alternative world view both to Galenism and to mechanism. The thought of Paracelsus and of Van Helmont, in both its antecedents and its potential implications for pathology, has been too well spelled out, particularly by Walter Pagel, to require an extensive rehearsal here. ${ }^{41}$ Suffice it to say that in their

physician, (Willis, op. cit., note 29 above, p. 655), and "with much adue, prevails over the disease" herself (ibid., p. 665). When nature is too weak to expel its "recrements", it deposits them on the lungs (Willis, op. cit., note 3 above, p. 107). The vital spirits, when sufficiently strong, robust, and "possessed of a governance" (regimine) can perform their offices in the blood by "as it were, some wise discretion" (velut discretione quadam sagaci, ibid., p. 196). Brown has noted the same sort of mixing of "Descartes-like mechanical analogies" with other types of explanation in Willis's work on the anatomy of the brain (Brown, (1977), op. cit., note 27 above, p. 50).

${ }^{40}$ See Walter Pagel, Paracelsus, an introduction to philosophical medicine in the era of the Renaissance, Basle, S. Karger, 1958, pp. 333-343; also Hans Kangro’s article on Sennert in the Dictionary of scientific biography, New York, Charles Scribner's Sons, 1975, vol. 12, pp. 310-313. A glance at the table of contents of Sennert's De febribus of 1619 reveals the traditional framework in which it is organized. It is a thoroughly academic piece of work being the general doctrine of Fevers which he had been teaching fo, many years in public lectures at the Academy of Wittenberg (Sennert, op. cit., note 9 above, sig. $a_{4}{ }^{v}-a_{5}{ }_{5}$ ). Even his effort at the reconciliation of disparate schools of natural philosophy reflects a scholastic approach to knowledge, the major statement of which appeared in the same year as his work on Fevers (De chimicorum cum Aristotelicis et Galenicis consensu ac dissensu liber I., controversias plurimas tam philosophis quam medicis cognitii utiles continens, Wittenberg, 1619).

${ }^{41}$ For Paracelsus, see Pagel, op. cit., note 40 above. His companion work on Van Helmont, (Cambridge University Press, in press) will be most welcome since his Jo. Baptist Van Helmont. Einführung in die Philosophische Medizin des Barock, Berlin, Springer, 1930, is not widely accessible. For the present discussion I have found particularly useful the concise and clear accounts of Paracelsus and Van Helmont in Pagel's Dictionary of scientific biography entries op. cit., note 40 above, as well as his 'Van Helmont's concept of disease - to be or not to be? The influence of Paracelsus', Bull. Hist. Med., 1972, 46: 419-454 (hereinafter cited as Pagel, 'Van Helmont's concept of disease'). See also Walter Pagel, The religious and philosophical aspects of Van Helmont's science and medicine, Baltimore, Md., Johns Hopkins Press, 1944, pp. 34f., 99; Davis, op. cit., note 23 above, pp. 156-158. Regarding Paracelsus` and Van Helmont's own 
writings the realms of the "biocentric" or life-domain of Aristotelian and Galenic thought is not penetrated by the inanimate, as it was by the Cartesian Willis, but rather the reverse. Or perhaps it would be better to say that there is an interpenetration and loss of boundary lines between the two.

One sees this particularly in Helmontian pathology. True, it is a different lifedomain, one of seeds, independent entities, and causes equipped with their own lifeschedules and psychic capacities (both instrumental and emotional). But it is this lifedomain that expands and virtually takes over. The immaterial gains ascendancy. Physiology becomes psychology; natural philosophy becomes moral philosophy; anatomy and matter in motion give way to mystical insight. In its pure form, Helmontianism does indeed present a distinctly different world view.

This can be seen more clearly if we look again at fermentation. In Helmontian terms, fermentation is not Galenic or Aristotelian putrefaction and has very little to do with their descendant, Willisian fermentation. For one thing, in Van Helmont's thought, the emphasis is on the thing, not the process, on the ferment, not fermentation. Second, despite the "thingliness", ${ }^{42}$ of this "Formal Ens", this "invisible. dynamic agent", 43 it is immaterial, "neither Substance, nor Accident, but Neutral, as Light, Fire, etc. stored or laid up from the beginning of the World ... for the preparing and exciting the Seeds of Things." It carries only "some Allusion or Similitude with the Leaven or Ferment, Bakers or Bruers use...."44 This is a far cry from the materialism of either Galenism or Willis and has little in common with either the vitalistic faculties of the former or the psychic powers of nature invoked by both. Only rarely is there even a hint of an overlap between the notions of Willis and those of Helmont, as when Willis spoke of the ferment in the heart. ${ }^{45}$

More typically, Willis's apparent use of Helmontian terms does not withstand examination. When discussing the contagion of plague, for example, Willis spoke of "the seeds of the pestilential contagion", "the seeds of the venom", "the venomous miasm", and "the ferments of the venom". But I seriously doubt that these are deliberate reflections of Helmontian thought. There is a long-standing practice, within discussions of the contagion of plague particularly, of talking about "seeds", (e.g., Fracastorius) and "ferments", (e.g., Sennert). ${ }^{46}$ Besides, in another place, Willis

writings on Fevers, see notes 8 and 9 above. In Van Helmont's treatise, his own views are largely expressed from $\mathrm{Ch}$. $\mathrm{X}$ to the end, particularly $\mathrm{Ch}$. XI, XIII, XVI, and XVII. The last two chapters did not appear until 1644.

42 The tralislator Chandler's very expressive term for quidditas e.g., the title of Ch. XVII.

43 Pagel, 'Van Helmont's concept of disease', op. cit., note 41 above, p. 439.

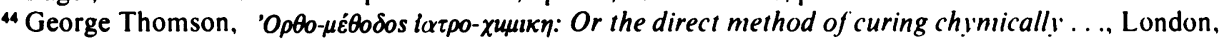
1675 , sig. $\left[A_{8}\right]$. Thomson seems to imply that there is more than one notion of ferment around when he specifies, "ferment (according to Van Helm.) is a Formal Ens ...".

${ }^{45}$ Willis, op. cit., note 3 above, pp. 18, 89. He also speaks of the acid ferment in the stomach (ibid., p. 96).

${ }^{46}$ Ibid., pp. 153, 154, 158, 160; H. Fracastorius, De contagione . ... trans. and notes by W. C. Wright, New York, Putnam`s Sons, 1930, p. 10 and note 5; Daniel Sennert, De febribus, 2nd ed., Wittenberg. 1628. Bk. IV, Ch. 3, pp. 395, 397f. In likening the contagious miasm to a fermentation rather than putrefaction, Sennert might have been influenced by Paracelsus but the context suggests otherwise. Despite being roughly contemporary with Van Helmont, it is highly doubtful that Sennert was influenced by him (Pagel, op. cit.. note 40 above, p. 333). See next note. 


\section{Thomas Willis and the fevers literature of the seventeenth century}

referred to these seeds as a "confusion of atoms".47

More work needs to be done to establish the precise intellectual constituents in Willis's doctrine of Fevers, but it does seem likely to me that his work is a fairly conservative transformation (almost translation) of Galenic doctrine into a "modern" corpuscularian materialism and that his ideas have quite rightly been identified as mechanistic and not Helmontian..$^{48}$ It is true that Willis's "principles", the constituent parts of the blood, were of Paracelsian inspiration and that they remain chemicals, rather than being reducible to Cartesian corpuscles. But it is also correct to see Willis's explanation of fever and of Fevers as a very "materialistic extension of the Paracelsian chemical theory". ${ }^{49}$ Conversely, Van Helmont proceeded in precisely the opposite direction of immaterial spirituality. He even objected to what he regarded as a misplaced materialism in Paracelsus' doctrine of the tartaric causes of disease. ${ }^{50}$

Up to this point I have tried to touch upon what appear to be the major intellectual trends in the Fevers literature between about 1558 and 1676, namely, Galenic traditional or "neoclassical", mechanistic materialism as reflected by Willis, and Paracelsian-Helmontian spiritualism. I have also suggested that, in the case of the neo-classicists and mechanistic materialists at least, the writings on Fevers are derivative, that is, they employ ideas and concepts which came largely from some place other than the logical necessities inherent in the subject of Fevers or from either clinical or experimental experience. ${ }^{31}$

If this is so, we are entitled to look elsewhere for possible reasons as to why authors

\footnotetext{
${ }^{47}$ Willis, op. cit., note 3 above, p. 146f., and Fracastorius called his seeds "imperceptible particles". A work that appeared in the same year, (Whitmore, op. cit., note 11 above) engaged in a long discussion of contagion which the author explicitly connected to Fracastorius and, after him, to Sennert, who, he suggested in one instance (p. 89), imitated Fracastorius. In view of the fact that Whitmore had been at Oxford and was made an Honorary Fellow of the College of Physicians at the same time as Willis, the influence of one on the other cannot be ruled out, but Whitmore is very explicit about the antecedents of his views and gives no hint of any knowledge of Willis's ideas. He clearly reflects a long-standing tradition in which he refers to the fact that some authors say contagion is a poison, "others a certain fermentation working like poyson" (ibid., p. 8). Whitmore also links fermentation to putrefaction (pp. 9, 15, 39) and, in fact, claims to follow Fracastorius in rejecting an atomistic account (p. 29) for a chemical one (p. 40).

${ }^{48}$ Brown, (1970), op. cit., note 27 above, p. 20f., and particularly his fn. 39 which contains a long quotation on this very point by the friend and contemporary of Willis, George Castle. On Castle, see Frank, op. cit., note 16 above, pp. $68 \mathrm{f}$., $195 \mathrm{f}$.

${ }^{49}$ Ibid., p. 165f.; Davis, op. cit., note 23 above, p. 169f., although it will be seen that my conclusions about the sources of Willis's Fevers doctrine do not entirely coincide with those offered by Davis, ibid., pp. 168-170.

so Pagel, 'Van Helmont's concept of disease', op. cit., note 41 above, p. $438 \mathrm{f}$.

"11 For example, it does not necessarily' follow from the discovery of the circulation of the blood that the Galenic doctrine of Fevers must be seriously revised, or at least revised in the particular way that Willis did it, his claim to the contrary notwithstanding. Harvey saw no such need. Nor did Helmontians, with a very different doctrine of Fevers, feel obliged to deny the circulation. On the contrary, George Thomson was quite interested in it (Charles Webster, 'The Helmontian George Thomson and William Harvey: the revival and application of splenectomy to physiological research', Med. Hist., 1971, 15: 154-167). The same could be argued, I believe, regarding anatomical and physiological discoveries before 1676. More likely, Galenism's general loss of credibility and the coincidently increasing explanatory power of chemical and corpuscularian theories, made the latter preferable rather than necessary, and only in some circles. See Owsei Temkin, Galenism: rise and decline of a medical philosophy, Ithaca, N.Y., Cornell University Press, 1973, Ch. IV, 'Fall and afterlife', esp. pp. 152-166.
} 
of the Fevers literature chose the particular intellectual ingredients they did. For example, underlying religious sensibilities might be expected to generate, perhaps often unconsciously, a priori commitments as to the nature of Nature which would make some types of explanation more congenial, more persuasive or meaningful, than others.

Pagel has argued that Van Helmont's "fundamental positions in Medicine grew out of his religious conviction, his belief in creation", and there is reason to believe, even if it is difficult to prove, that some Helmontians at least, were attracted by similarly felt convictions. ${ }^{52}$ Willis's less than thorough-going corpuscularianism, on the other hand, could well have been influenced, in part, by his desire to escape the religious pitfalls of rank materialism. With what appears to be considerably more than coincidence, Willis, the determined Anglican, dedicated his Cerebri anatome to the Archbishop of Canterbury. On what sounds like a defensive note, he pointed out to his patron that there was no reason why explanations offered in philosophy should derogate from religion, as if "all that should be attributed to second causes did take away from the first". .33

In fact, the number of possible "ulterior" motives for Willis's having written as he did is rather high, and some have already been suggested in connexion with other subjects. For one thing, he had a rather speculative turn of mind, fond of comprehending some important area of medical theory under a "hypothesis". .44 One could view his treatise as something of a tour de force meant as much to illustrate the plausibility as to argue for the truth of his fermentation theory. ${ }^{\text {ss }}$ While many who commented on his work took it more literally as a statement of what Willis believed to be the truth, it was accepted in some quarters as something akin to what we could call a "working hypothesis". 36

Unfortunately, however, as soon as the suggestion is made that Willis wanted to show how the phenomena of an important subject like Fevers were compatible with or even explained by a particular natural philosophy, ${ }^{37}$ this in turn simply raises again the question of, Why?

\footnotetext{
32 Pagel, (1944), op. cit., note 41 above, p. 41. See also Peter Niebyl, 'Science and metaphor in the medicine of Restoration England', Bull. Hist. Med., 1973, 47: 356-374.

${ }^{33}$ Thomas Willis, Cerebri anatome, London, 1664. For a more general discussion of the religious problems which faced proponents of corpuscularianism, see Michael Hunter, Science and society in Restoration England, Cambridge University Press, 1981, Ch. 7, 'Atheism and orthodoxy'. I am grateful to Dr. Hunter for permitting me to read his work in manuscript.

34 Frank, op. cit., note 16 above, p. 169. Frank comments repeatedly on Willis's speculativeness (e.g., ibid., pp. 223, 233, 237, 293). Willis himself confessed to this tendency (Cerebri anatome, Geneva, 1680. Preface to the Reader).

ss As does Frank, op. cit., note 16 above, p. 166. Also see ibid., p. 291, where Frank argues that, particularly under the influence of Boyle, there was a more or less tacit understanding, among the Oxford physiologists with whom Willis was associated, that "hypothesis" meant tentative explanation, and that, nevertheless, this was not always understood outside the group. Willis too seems to suggest this, op. cit., note 38 above, Preface.

56 As did Goodall, op. cit., note 2 above, p. 49f. See also ibid., p. 140. Willis himself seems, very occasionally, to talk this way (e.g., Willis, op. cit., note 3 above, p. 27). However, as with so much seventeenth-century natural philosophy, the hypothesis was well in advance of the work.

57 Davis, op. cit., note 23 above, p. 138, suggests that there was a long-standing tradition which used fever to "promulgate, test, and illustrate" theories, citing, as an example, an author from the fifteenth century.
} 


\section{Thomas Willis and the fevers literature of the seventeenth century}

While not addressing himself to Willis's doctrine of Fevers in particular, Professor Frank has offered us reasons why Willis may have written as he did. After giving us a very rich and detailed account of Willis's circle of friends and collaborators, Frank has very reasonably argued for the importance of "shifting patterns of contact and communication in unique temporal and geographic loci" in which these men shared their common problems, concepts, terminology, and techniques of study. In particular, Frank has shown how they shared a corpuscularianism that was chemical rather than simply atomistic, and a reluctance to espouse Helmontian metaphysics. ${ }^{58}$

Willis thought as he did, then, because of the company he kept. Why did this Oxford group think as they did? An answer for this layer of the onion is offered by Brown, who saw in these elements of a common natural philosophy the momentum of tradition, the conservative influence of Harvey, the central importance of experimentation also because of Harvey, and the careful political course steered between the slavish conservatism of Galenism and a "witless" subscription to mechanism. Had their mechanism been purer, Brown argues, it might possibly have brought this university group into collision with popular opinion and common theology just when university men were playing a prominent role in the outraged reaction to the materialist Hobbes in the 1650s and 1660s. ${ }^{39}$

All of these layers of causes fit the contours of each other fairly well, granting that the final result is more an object of plausibility than of proof. ${ }^{60}$ But just as we think we are beginning to discern the whole onion, we discover we have lost sight of its germinal centre - Willis's treatise on Fevers which had the potential of being nourished by interests other than those of a particular persuasion in natural philosophy. Such other interests could include, for example, those of the practising physician; and that is quite another matter, another onion so to speak.

To suggest this possibility is not to say that the Fevers literature was exclusively practical, that it was devoid of a disinterested philosophical side, that there was no "pathology" of Fevers as such. After all, Fernel's treatise was a part of his 'Pathologia', his work on the treatment of Fevers not being written until the very end of his life. Indeed, though most Fevers literature of the late sixteenth century included consideration of treatment, one gets the impression, reinforced by Lonie's essay, that the intent behind it was often more academic than practical. Sennert's work seems largely to fall into that category, and possibly those of Descartes and Borelli as well. ${ }^{61}$

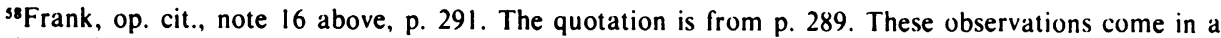
section, 'Ideas and social interaction', in which Frank espouses a philosophy of the history of science which emphasizes the combination of intellectual coherence and social contiguity. See also ibid., p. 246.

s9 Brown, (1977), op. cit., note 27 above, pp. 51-53.

${ }^{60}$ Perhaps somewhat in the way that Willis's Fevers doctrine seemed to those contemporaries who shared his views on what constitutes meaningful explanation!

${ }^{61}$ Or, rather an anonymous disciple of Descartes; Le monde de Mr. Descartes, . . avec un discours de l'action des corps, et un autre des fièvres, composez selon les principes du même auteur. Paris, 1664: G. A. Borelli, Delle cagioni delle febbri maligne della Sicilia. Negli anni 1647 e 1648 . . . con una appendice della natura della febbre in comune ..., Cosenza, 1649. For a late example which explicitly eschews considerations of treatment see Pyretologia or a history of feavers composed according to such use of the parts. circulation of the blood..., London, 1674.
} 


\section{Don G. Bates}

But, in the seventeenth century, the issue of how to treat Fevers, and indeed most diseases, was a highly contentious one in which many different views were struggling for legitimacy and orthodoxy. Whether it was because access to the printing press was reaching down into the lower social levels of practitioners, or because the conflict was reaching up into the ranks of the élite, it does seem that the Fevers literature of this period was being much affected by these social upheavels. As a result, the social implications of any doctrine of Fevers could be considerable if it could be read as prescribing the way that medicine should be practised.

This raises two possibilities: that a particular doctrine of Fevers was written with a conscious or unconscious regard for the support of one type of medical practice at the expense of another; or, if not written with that intent, at least appropriated by some group of practitioners for the same purpose. Did Willis write with an eye on such social consequences? Or ought we to understand his work only as a part of the academic and philosophical tradition? On the one hand, as we have seen, he certainly did fit into an academic philosophical group, but on the other hand, as we shall see, his work was clearly enlisted by others in the struggle for social position. What, therefore, can be said about Willis's own intentions?

It is highly doubtful that it will ever be possible to say anything very categorical about Willis's own motives. ${ }^{62}$ Some aspects of his career argue for this type of social influence, others against. On the affirmative side, for example, by the time his treatise was finished in 1658, Willis had been for many years earning his living as a physician. After going to London in 1667, he developed a very large and successful practice there. ${ }^{63}$ Consistent with this, his treatise was not advocating new forms of treatment, but new ways of understanding the traditional treatment of Fevers. Finally, he did become a Fellow of the College of Physicians and got from some of its spokesmen at least tacit approval for his Fevers doctrine. ${ }^{64}$ All of these things, it could be argued, influenced his choice of the particular features which he propounded in his doctrine.

These arguments for the affirmative are not very weighty, however, and are counterbalanced by others. For one thing, his attitude to treatment was remarkably eclectic, or perhaps one should say that his explanatory hypotheses seemed capable of justifying both empirical and conventional treatment, even that used by healers whom he saw as highly undesirable. ${ }^{65}$ The range of his flexibility in this regard can be exemplified by his explanation of the effects of an amulet in corpuscularian terms. ${ }^{66}$

Willis was, indeed, against crude empirics and shared the same contempt for unlettered practitioners that exercised so many of the university-educated physicians, ${ }^{67}$ but his theme from his first publication to his last was not what treatment

62 If indeed Willis himself ever knew!

${ }^{63}$ Frank, op. cit., note 16 above, pp. 179, 194. See also Willis, op. cit., note 16 above, sig. [A $A_{4}$ ].

${ }^{64}$ College reactions are discussed further, below.

${ }^{65}$ He seriously considered both "Empiric and Dogmatic" remedies, and, even though the former were administered by mountebanks (agyrtis) and old women, they were not uncommonly more effective than what was administered methodically (Willis, op. cit., note 3 above, pp. 39-41; see also pp. 50, 55; and in his last writings, Willis, op. cit., note 16 above, Pt. II, pp. 40f., 98-101).

${ }^{66}$ Willıs, op. cit., note 29 above, p. 597.

${ }_{67}$ "Empiricks, . . . quacking Juglers and old women", "medicasters", "pseudochymists", and "executioners" (Willis, op. cit., note 16 above, Pt. I, sig. $\left[A_{2}{ }^{r}-A_{3}{ }^{i}\right]$ ). 


\section{Thomas Willis and the fevers literature of the seventeenth century}

was valid and what not, but that whatever treatment was given, it should be given with a full understanding of its operations on the body. He wanted a rational therapeutics and indeed a pharmacology, because "a Medicine rashly administered is but casting a die for a man's life". ${ }^{68}$ Such a stand could be used to support not only traditional medicines, but new ones like chemical remedies as well, provided their use had been rationalized.

The evidence for Willis's relationship to the College of Physicians is also equivocal. When he composed his treatise he was not living in London and was not a member. It was six years before a College member made any comment on his treatise. Moreover, it has been argued that prominent College members were unsympathetic to corpuscularianism when his treatise first appeared. ${ }^{69}$ True, while still in Oxford, he was made an Honorary Fellow, ${ }^{70}$ but there is little evidence of his active involvement with the College during his years in London. ${ }^{71}$ Perhaps it is reasonable to conclude that Willis was too closely connected with an orthodox education and the orthodox practice of medicine to have compromised these seriously by his new doctrine of Fevers, but that he did not construct it so as to please the College of Physicians either. Indeed, since Willis was very well connected socially, in early Restoration England, his Fellowship may quite easily have been in spite of, or without regard to his theories. ${ }^{22}$

So much for our speculation as to why Willis wrote a treatise on Fevers and why it took the particular form that it did. What about the use to which others put his ideas? For, if Willis wrote in the intellectual and social milieu of academe and philosophical discourse, there was nothing to stop others from appropriating his ideas in the broader interests of social polemic; and so they did.

Possibly the earliest favourable notice (1662) came from the practitioner, and a soon-to-be-notorious polemicist, Henry Stubbe. Stubbe had no difficulty in accepting the corpuscularian basis of Willis's doctrine nor, in fact, in finding Willis's notions on

\footnotetext{
${ }^{68} \mathrm{Ibid}$., Part II, sig. $\mathrm{A}_{2}{ }^{\mathrm{r}}$. Medicine in the hands of those who don't know what they are doing is "like a sword in a blind man's hand" (Willis, op. cit., note 3 above, p. 111). "The bare empiric without method and ... reasons is of little value" (ibid., sig. $\mathrm{H}_{4}$ ). To practise medicine without an exact knowledge of the parts and passages of the body would be like repairing a clock knowing only Aristotle's theory of natural motion (Willis, op. cit., note 16 above, Pt. II, sig. $\mathrm{A}_{2}{ }^{\mathrm{v}}$ ). Willis hoped that Physick would "grow to a true Science and be practised with greater certainty, not inferior to the Mathematicks" (Willis, op. cit., note 38 above, Pharm. rat., Pt. I, sig. $\left.\left[\mathrm{A}_{3}{ }^{\mathrm{r}}\right]\right)$.

${ }^{69}$ Brown, (1977), op. cit., note 27 above, p. 44.

70 in December 1664, along with at least sixty-five other physicians from various parts of England (W. Munk, The roll of the Royal College of Physicians of London, 2nd ed., London, Royal College of Physicians, 1878, vol. 1, pp. 319-351. See also Sir George Clark, A history of the Rolal College of Physicians of London, Oxford, Clarendon Press, 1964, vol. 1, pp. 312-317). Months later, one of these, Edmund Meara, published an attack on Willis's doctrine along traditional lines (op. cit., note 25 above, cites the 1667 edition but the first edition was in 1665 ).

${ }^{71}$ Munk, op. cit., note 70 above, pp. 338-342. As an Honorary Fellow. Willis could not hold office (Clark, op. cit., note 70 above, p. 314). In interpreting Wood's remark about Willis's heavy labours in his "Faculty" as indicative of his efforts on behalf of the College, Hansruedi Isler (Thomas Willis 1621-1675, doctor and scientist, New York, Hafner, 1968, p. 42f.) is surely mistaken in thinking that "Faculty" referred to the College rather than merely to the practice of medicine, a common use of the term at the time.

${ }^{2}$ Besides being Sedleian professor of Natural Philosophy at Oxford, he was the brother-in-law of John Fell, Dean of Christ Church, Oxford. His Cerebri anatome was dedicated to the Archbishop of Canterbury and his invitation to come to London to practise came from that quarter.
} 


\section{Don G. Bates}

fermentation and Fevers second in greatness only to the work of William Harvey. This endorsement appears to have stemmed from Stubbe's involvement with Willis and the Oxford circle, ${ }^{73}$ but we shall leave a more complete assessment of the motives of this complex man for others to unravel. ${ }^{74}$

Of more explicitly social purpose is an anonymous work of 1665 . The author, apparently a layman, made a temperate plea for improved relations between the College of Physicians and the apothecaries. Among other things, he saw merit in rational chemists, and invoked Willis to support his claim that new information about the effects of medicine on the blood and other juices had now come to light. ${ }^{75} \mathrm{~A}$ negative response to this layman's suggestions from a College member did not appear until some years later and we shall not pursue this particular argument further. ${ }^{76}$ But in the same year as the original proposal a second tract appeared, Marchamont Nedham's Medela medicinae." This was not temperate, and the College was not slow in replying.

Even without the book, Nedham's activities would have been provocation enough for, at the same time, he was playing an active role in efforts to establish the Society of Chemical Physicians which would have been a direct challenge to the monopoly of the College. ${ }^{78}$ The book itself, however, was a masterpiece of aggravation. In particular, Nedham seemed to delight in using the College's own acknowledged authorities and even their own members to tear down that institution's claims to be the keeper of orthodoxy. Among the "noblest and most authentic writers", he found support not only from Fernel and Sennert, but, with telling effect, from that illustrious pillar of the College itself, William Harvey. ${ }^{79}$ Nedham even had the temerity to dedicate his polemic to the Marquis of Dorchester, a complete stranger to the author, but to the College a patron and Honorary Fellow. ${ }^{80}$

It could hardly have distressed this professional picador when one of his shafts struck close to home apparently by accident. In the interval between completion of Nedham's manuscript and its publication, Thomas Willis, whose ideas he used against the College, had been made one of its Honorary Fellows. ${ }^{81}$ In Nedham's hands,

\footnotetext{
${ }^{73}$ Frank, op. cit., note 16 above, p. 237 and fn. 83 and 84.

${ }^{74}$ For one version, see J. R. and M. C. Jacob, 'The Anglican origins of modern science', Isis, 1980, 71: 251-267, see p. 260f.

${ }^{75} \mathrm{~T}$. M., A letter concerning the present state of physick, and the regulation of the practice of it in the kingdom. Written to a doctor here in London, London, 1665, p. 42.

${ }^{76} \mathrm{C}$. T., Some papers writ in the year 1664 [sic for 1665]. In answer to a letter concerning the practice of physick in England, London, 1670. The author made clear his College membership but various ascriptions to Christopher Terne and Timothy Clarke are doubtful.

"Marchamont Nedham, Medela medicinae. A plea for the free profession. and a renovation of the art of physick, out of the noblest and most authentick writers, London, 1665.

${ }^{78}$ Nedham's prefatory letter to Edward Bolnest, Medicina instaurata, London, 1665. See also P. M. Rattansi, 'The Helmontian-Galenist controversy in Restoration England', Ambix, 1964, 12: 1-23, esp. pp. 10, 15; and Clark, op. cit., note 70 above, pp. 322-326. One of the signatories to the petition for the New Society was Dr. Sheldon, Archbishop of Canterbury and Patron of Willis.

79 also Zacutus, Horstius, Kircher, Forestus, Galen, and Hippocrates.

${ }^{80}$ Nedham made his own lack of acquaintance explicit in his dedicatory letter. For the Marquis and the College, see Munk, op. cit., note 70 above, pp. 281-292: Frank, op. cit., note 16 above, p. 29; and Clark, op. cit., note 70 above, p. $284 f$.

"Nedham's book was licensed on 2 September 1664 and the dedicatory letter dated 26 November.
} 


\section{Thomas Willis and the fevers literature of the seventeenth century}

Willis's rejection of traditional notions about critical days, humours, and uroscopy, and his use of the movement of the blood, the five Paracelsian principles, and chemical analysis of the urine, became a weapon in the fight against the sacred cow of College Galenism. ${ }^{82}$ In order to avoid the thrust of these arguments, College apologists were obliged to show that Willis's arguments were not aimed at them.

The details of those ripostes, by such Collegians as Sprackling, Twysden, and Hodges, need not concern us in more than the barest outline which will serve to illustrate how the complexity and double-edged possibilities of Willis's theories could be both boon and bane of the College's existence. Sprackling, for instance, conceded that Willis's new doctrine of critical days superseded that of Galen, spoke favourably of his doctrine of fermentation, corrected Nedham's rendition of Willis's attitude to uroscopy, taunted him for criticizing Willis's use of bleeding in smallpox and measles, and chastised him for not recognizing that Willis's use of the five Paracelsian principles was only by way of a manner of speaking. ${ }^{83}$ Twysden, too, saw Willis's principles as an heuristic device and was therefore capable of reconciling both him and Paracelsus with "the ancient Philosophers". ${ }^{84}$ Likewise, Hodges, a friend and collaborator of Willis's at Oxford, insisted that that author spoke only of atomical effluviums acting like a ferment and criticized Nedham for converting Willis's simile into an assertion of fact. ${ }^{85} \mathrm{~A}$ decade later, although he expounded Willis's doctrine of Fevers at length, Charles Goodall was still basically arguing the same thing - Willis's theory of Fevers was a "hypothesis", a way of philosophizing, but not an occasion for calling into question the College's basic claim to have the knowledge and approach to treatment best qualified to justify their monopoly over licensing. ${ }^{86}$

Willis was honoured by the College in December. Nedham characterized him as "one of our University professors" (Nedham, op. cit., note 77 above, p. 238), and, as Stubbe had done, "the Ornament of our Nation next to immortal Harvey" (ibid., p. 237), an expression of praise which the College apologist Goodall then turned back on Nedham (Goodall, op. cit., note 2 above, p. 143f.).

${ }^{82}$ Nedham, op. cit., note 77 above, pp. 115, 265, 322f., 332ff., 357, 378f., 380, 382, 415.

${ }^{3}$ Robert Sprackling, Medela ignorantiae: or a just and plain vindication of Hippocrates and Galen from the groundless imputations of M/archamont] N/edham] ..., London, 1665, pp. 15f., 65-67, 93-99, 143-145, 154f. Sprackling dedicated this swift reply (licensed 24 February 1664/5), to Glisson, whom, along with College stalwarts like Harvey, Ent, and Wharton, he invoked with approval, (e.g., ibid., pp. 51, 153).

34 John Twysden, Medicina veterum vindicata: or an answer to a book entituled Medela medicinae; in which the ancient method and rules are defended . . . against the calumnies. . . of Mar/chaniont] N/edham/, London, 1666, pp. 174-176. Again, College luminaries like Harvey, Glisson, Wharton, etc., were called upon.

ss Nathaniel Hodges, Vindiciae medicinae et medicorum: or an apology for the profession, London, 1666, p. 149f. He seems to be alluding to Nedham's remarks (Nedham, op. cit.. note 77 above, pp. 111-115), where Sennert figures as largely in his argument as Willis does. See also ibid., p. 181f., where Kircher and Helmont are likewise invoked. Hodges was attacking both Nedham and George Thomson, who will be discussed below, as well as the apothecaries and the "Society of Chymical Physicians". Hodges's association with Willis is discussed by Frank, op. cit., note 16 above, p. 240.

${ }^{86}$ Goodall, op. cit., note 2 above, p. $45 f$., states Huybert's basic argument to which he is responding. Goodall's argument permeates the whole book, but see esp. p. 49 where he claims that differences over Galenical, Spagirical (i.e. Willisian), and Sylvian hypotheses are "rather verbal than real"; different hypotheses still lead generally to the same cures (p. 52); there is little prejudice to the Arts by "this freedom of Philosophising" (p. 53). See also pp. 54f., 106. Goodall agrees that "the Theories of Fevers . . may possibly of late, by the industry of Collegiate members have been built upon more solid foundations than formerly", without rejecting "the good old remedies and methods of practice", and quotes Willis to this 


\section{Don G. Bates}

The College had no monopoly on Willis, or even on an antipathy to Nedham. George Castle, who practised in London, but who is not listed as a member in the College Roll, in response to Nedham also invoked the name of Willis. Unlike the Collegians, Castle had no difficulty in accepting his corpuscularian philosophy, showing the upstart Nedham that it was easily reconciled with traditional therapy. ${ }^{87}$ Like Hodges, Castle had been an Oxford friend and collaborator of Willis.

The connexion which various commentators made between Willis and Helmont is itself instructive. Castle, for instance, took considerable pains to dissociate Willis's materialistic philosophy from Helmontian mysticism. ${ }^{88}$ Others, however, saw things differently. Nedham, who looked favourably upon both Helmont and Willis, claimed that the latter, along with several others, had "lighted their tapers at the Torch of Helmont".89

One might have expected some consistency on this point between Nedham and another anti-College, anti-Galenist polemicist, George Thomson. A more thoroughgoing Helmontian, Thomson began his attack in the same year, 1665, and was active in the same enterprise: promoting the Society of Chymical Physicians. ${ }^{90}$ Thomson, however, accused Willis of plagiarizing Helmont and of having appropriated Paracelsian doctrine which he then "trimly polished for sale" but which was "to be rejected, as being ... false ... also dangerous and destructive if made use of, according to what he hath delivered for the Cure of Diseases".91 By contrast, another Helmontian, writing in the same year that Thomson was denouncing Willis, referred favourably to "the ingenious Dr. Willis". ${ }^{92}$ It is inconceivable that these confused and

effect (p. 151). Goodall was responding not to Nedham (to whom he alludes, p. 150), but to Adrian Huybert's $A$ corner-stone laid towards the building of a new College .... London, 1675.

But Goodall also quotes Willis and his theory of diseases to suggest that medicine now is "more firmly founded and established upon Anatomical observations" which lead to "more appropriate methods of the cure of every affection" (p. 91)! A "method" is a programme of treatment in contrast to mere dosing with empirical remedies. (See my 'Sydenham and the medical meaning of "method"', Bull. Hist. Med., 1977, 51: 324-338.) A recurring and insistent refrain of Goodall's is that, no matter what the treatment, including chemical remedies, it is the rationale and hence the physician's background education which is critical. See, for example, Goodall, op. cit., note 2 above, pp. 118, 126f., 131f., and 139 (where he quotes Willis), 147f., 157. We have already seen that this was Willis's stand (see note 68 above), and the same refrain was followed by other College apologists (e.g., Hodges, op. cit., note 85 above, p. 148). Indeed, it is arguable that it was the rationalism of Galenism and Hippocrates, of Cartesianism, and Boyle, more than any particular doctrine or therapeutics which members of the College sensed as the central value upon which their professional orthodoxy must rest. It linked the old with the new and protected the learned and the educated from the incursions of those who were not. See Keith Thomas, Religion and the decline of magic, Harmondsworth, Middx., Penguin Books, 1971, pp. 773, 786-789.

${ }^{87}$ George Castle, The chymical Galenist: a treatise wherein the practice of the ancients is reconcil'd to the new discoveries in the theory of physick ... in which are some reflections upon ... Medela medicinae, London, 1667.

${ }^{88}$ Frank, op. cit., note 16 above, p. 195; Brown, (1970), op. cit., note 27 above, p. 20 f., fn. 39.

${ }^{89}$ Nedham, op. cit., note 77 above, p. 95. For instances of his appeals to Helmont, see ibid., pp. 149. 156f., $238 \mathrm{f}$.

90 Webster, op. cit., note 51 above, contains biographical details and a bibliography of Thomson`s writings. See also Rattansi, op. cit., note 78 above, p. $16 f$.

${ }^{91}$ Thomson, op. cit., note 44 above, pp. 62, 63. See also p. 83 f. Willis was contradicted even in the title of one of Thomson's works of 1670.

$92 \mathrm{Wm}$. Simpson, Zymologia physica: or a brief philosophical discourse of fermentation. London, 1675. p. 245. 


\section{Thomas Willis and the fevers literature of the seventeenth century}

conflicting claims about Willis's connexion with Helmont had a primarily intellectual intent. Helmontianism was being used as a fundamental weapon against established orthodoxy in that, in the eyes of various of its disciples, it lent itself to chemical remedies, empirical treatment, the rejection of Galenic patho-physiology, and the modern anatomical-physiology of Harvey and others. In other words, the thought of Helmont was adaptable to social movements fundamentally subversive of the social order. It is obvious that Willis, and what he stood for, was the subject of a tug-of-war between contending sides.

Undoubtedly, a more careful study of the various tracts would be rewarded with a clearer picture of who thought what, in connexion with which cause. Nevertheless, it does seem, on the face of it, that when a man's thoughts become ammunition for social battles, motives extraneous to particular intellectual positions can easily take precedence so that the neat logical consistencies and faithful renderings of the original, which we strive to uncover in intellectual history, may simply not be there. In Restoration medicine, it may also be true that institutions like the College, or groups like the Chemical Physicians, or Helmontians, cannot be said to have a common policy or point of view. Rather, each individual, more or less self-appointed, spoke out in the name of those with whom he wished to associate and whose interests he shared, but from the point of view of his own personal and not always visible concerns. ${ }^{93}$

It may seem at this point that we have strayed far away from the Fevers literature. In actual fact, it is the Fevers literature itself, or at least a part of it, which has strayed from the subject of Fevers as its primary concern. The purpose of following this diversion has been to illustrate that, in the context of the seventeenth century, the Fevers literature could both serve and be generated by a wide variety of social concerns that had little to do with the purposes of academe, philosophical discourse, or what we are inclined to think of as science.

A final dimension of the literature is its possible relationship to the natural setting, the disease environment in which its authors lived and from which they derived their clinical and social experience of Fevers. ${ }^{94}$ For several reasons this is a complicated subject. For one thing, it is conceivable that the type of author who wrote on Fevers changed over the period, as to educational background, social status, and motives for writing. ${ }^{95}$ The characteristics of his practice - numbers, social status of his patients,

\footnotetext{
${ }^{93}$ For a case study of precisely this process, see Andrew Cunningham, 'Sydenham versus Newton: the Edinburgh Fever dispute of the 1690s between Andrew Brown and Archibald Pitcairne', in Bynum and Nutton (editors), op. cit., note 6 above, pp. 71-98.

${ }^{94}$ For a general consideration of this relationship, see Guenter Risse, 'Epidemics and medicine: the influence of disease on medical thought and practice', Bull. Hist. Med., 1979, 53: 505-519.

${ }^{95}$ Despite his academic proclivities (Sherrington, op. cit., note 6 above, pp. 12, 152), Fernel emphasized the value of practice and the fuller experience of a large city like Paris (ibid., p. 156f.). Possibly changing attitudes to the need for medical education in England, after 1600, are suggested by Margaret Pelling and Charles Webster, 'Medical practitioners', in Charles Webster (editor), Health, medicine and mortality in the sixteenth century, Cambridge University Press, 1979, pp. 165-235, see pp. 189-191. Concerning the great growth in medical publishing (and the likely changing status of its authors), during the 1650 s, see Charles Webster, The great instauration; science, medicine and reform. 1626-1660, London, Duck worth, 1975, pp. 204-273. A likely example of a small-town physician breaking into print on the subject of Fevers

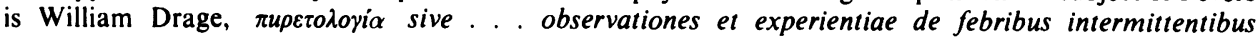


types of conditions he treated, location of his practice, etc. - could also have changed. ${ }^{96}$ Such things could have materially affected the exposure he had to these diseases and his ways of thinking about them. It is at least theoretically possible that any trends detectable in the literature reflect changes in the circumstances of the authors in the face of a stable disease environment.

But obviously, the converse is also possible. Changes in the disease environment are at least equally likely, if not more so. These could be changes in virulence, epidemicity, types of diseases prevailing, etc.; and there is nothing to rule out the possibility that both authors and disease environment were changing simultaneously.

To compound the problem, most of the information which we have on the disease environment is based on two unsatisfactory sources of evidence: the Fevers literature itself, which compromises the independence of the evidence; 97 or archival records which yield data independent of the literature, but data essentially about mortality patterns which are only vaguely related to the sorts of experiences with disease which could have influenced contemporary accounts. ${ }^{98}$

In this already lengthy survey, limitations of time, space, energy, and patience argue against any extended consideration of the disease patterns which painstaking research on archival records is gradually bringing to light, and which may some day help to illuminate some of the changes that were occurring in the Fevers literature. ${ }^{99}$ I

medicinae, London, 1665. He had had no training in dissection and was dependent for his information on his experience, especially with an epidemic in 1657 (p. 6).

96 There were extremes such as the astrological rural physician Napier, on the one hand, who practised medicine before and after 1600 , and, in a wide sampling of 60,000 or more case records left no trace of having treated any patients for epidemic diseases (personal communication from Michael MacDonald), while Sydenham sometimes treated "7 or 8 Febricants in a day" (Vaillant MS., op. cit., note 4 above, f. 15). Sennert claimed that Fever was the commonest problem to be tackled usefully by medicine (op. cit., note 9 above, sig. $a_{4}{ }^{\top}$ ). London, the environment which provided the experience of many English authors on Fevers, underwent substantial demographic and economic changes in the seventeenth century. (See Rattansi, op. cit., note 78 above, pp. 5-7.) For evidence of the effects of social status on disease, see Paul Slack, 'The local incidence of epidemic disease: the case of Bristol 1540-1650', in The plague reconsidered ..., Local Population Studies Supplement, Matlock, Derbyshire, Local Population Studies Society, 1977 , pp. 49-62; with respect to plague, idem, 'Mortality crises and epidemic disease in England, 1485-1610', in Webster, (1979), op. cit., note 95 above, pp. 9-59, see pp. 48f., 51, 57. Sydenham thought there was less mortality from smallpox among the untreated poor than among the badly doctored rich (Vaillant MS., op. cit., note 4 above, f. $23^{r}$ ). Willis observed that the epidemic pattern of a disease could be different in the countryside and small villages as compared to big cities (Willis, op. cit., note 29 above, p. 668). For comments on who was treated by what kind of healer, and for what sorts of conditions poor people might get treated, see Pelling, op. cit., note 95 above, pp. 182, $218 \mathrm{f}$.

${ }^{97}$ R. S. Roberts, in 'Epidemics and social history', Med. Hist., 1968, 12: 305-316, discusses the shortcomings of Charles Creighton's $A$ history of epidemics in Britain. from A.D. 664 to the extinction of plague, 2 vols., Cambridge University Press, 1891-94, owing to its heavy dependence on works written by British medical practitioners over the centuries (pp. 310-315). For a theoretical exposition of the problem and a case study, see Bates, op. cit., note 11 above.

98 See comments like Webster, (1979), op. cit., note 96 above, p. 6f., and Slack, in Webster, ibid., p. 58. The statement (The plague reconsidered, op. cit., note 96 above, p. 6), that "contemporary descriptions of the symptoms exhibited by past diseases are hard to find", needs refinement; descriptions which refer to the same epidemics being uncovered from archival records are usually, and descriptions of patterns which we can confidently identify are sometimes, hard to find.

${ }^{99}$ For a selected bibliography of current works on disease patterns, see Charles Webster, 'Medicine as social history: changing ideas on doctors and patients in the age of Shakespeare', forthcoming in a symposium celebrating the 50th anniversary of the Institute of the History of Medicine, The Johns Hopkins University, Baltimore, Md., October 1979. 


\section{Thomas Willis and the fevers literature of the seventeenth century}

shall limit myself instead to two possible trends which might reward further investigation. My observations are impressionistic and speculative, meant only to serve as suggestions for further research.

The birthplace of the classical literature on Fevers was the Mediterranean basin, an area which favoured intermittent Fevers and which may have been free of smallpox, at least in ancient times. ${ }^{100}$ By the seventeenth century, on the other hand, Northern European and British people, who had produced most of the literature we have considered, had experienced centuries of plague, at least two centuries of smallpox, and possibly a waning of intermittent Fevers relative to the continued ones such as typhus, typhoid, and the dysenteries. ${ }^{101}$ It does seem likely, therefore, that the discrepancy between the disease patterns reflected by ancient literature and those experienced by "modern" writers was considerable.

Whether the actual discrepancy grew in the period under consideration, or whether authors simply became increasingly conscious of it is a question of great complexity. But it does seem to me that a shift in the literature did occur away from the influence of classical literature and towards the contemporary disease situation.

This is least apparent with respect to intermittent Fevers. In the seventeenthcentury literature, as in Galen, these Fevers occupied a prominent position and the argument over their general pathogenesis, and highly characteristic fever patterns continued to hold a fascination which may suggest the grip of tradition as much as it does the continuing prevalence of the disease. ${ }^{102}$ Like plague, it was destined to disappear from these regions in the decades following the turn of the eighteenth century, but, like plague, it remained a disease to be reckoned with during the period in question. ${ }^{103}$

But the shift is more apparent with respect to the exanthemata, especially smallpox

\footnotetext{
100 It has recently been argued, though without much supporting evidence, that the literary record points to the second or third century A.D. as the most probable time when smallpox and measles established themselves among Mediterranean populations (W. H. McNeill, Plagues and peoples, New York, Doubleday, 1976, pp. 116-118). But, in our interpretations of ancient literature we are not much better off than seventeenth-century authors. See note 113 below.

${ }^{101}$ For smallpox, see note 114 below. Regarding malaria, see S. P. James, 'The disappearance of malaria from England', Proc. R. Soc. Med. (Epidemiology Section), 1929, 23: 71-87; L. W. Hackett, Malaria in Europe. An ecological study, London, Oxford University Press, 1937, p. 29f.; W. P. MacArthur, 'Malaria in England', Br. med. Bull., 1951, 8: 76-79; and L. J. Bruce-Chwatt and J. de Zulueta, The rise and fall of malaria in Europe. A historico-epidemiological study, Oxford University Press, 1980.

${ }^{102}$ Lonie (op. cit., note 6 above), has rehearsed the arguments surrounding the pathogenesis of intermittent Fevers. See also Augenius, op. cit., note 7 above, p. 177f. It was common, in the traditional literature, to designate even continued Fevers as tertian, quartan, etc. (e.g., Fernel, op. cit., note 18 above, p. 177). For echoes of these preoccupations a century later see, for example, Bauderon, op. cit., note 14 above, p. 15f.; Willis, op. cit., note 3 above, pp. 27-33; and Goodall, op. cit., note 2 above, p. 50. For twentieth-century arguments as to whether or not there was malaria in seventeenth-century England, see A. Davidson, 'Sydenham's experience of malaria', Janus, 1903, 8: 353-358, where he takes issue with Creighton's claim that Sydenham did not see it. The debate was taken up by James, op. cit., note 101 above. Thomas Mckeown, The role of medicine: dream, mirage, or nemesis? London, Nuffield Provincial Hospitals Trust, 1976, p. 42, rules out the likelihood of there ever having been much maıarıa in Britain, on meteorological grounds. But the issue is very complex (Hackett, op. cit., note 101 above, $\mathrm{Ch}$. 2). The sceptics have never, so far as I know, explained the remarkable impact of cinchona on Fevers authors in Willis's and Sydenham's time.

${ }^{103}$ For the departure of plague see Christopher Morris, 'Plague in Britain', in The plague reconsidered, op. cit., note 96 above, p. 43 .
} 
and measles. ${ }^{104}$ To see what was happening, it will be useful once more to compare Fernel and Willis. Fernel, reflecting the classical tradition, did not treat rashes as distinguishing characteristics of different Fevers. Rather, ne saw them as signs of the degree of virulence (or to speak in contemporary terms of "malignity"), with respect to the (mostly continued) Fevers which he did distinguish. ${ }^{105}$ Rashes were signs of pestilence, serious contagiousness, or, particularly in the case of petechiae, likely mortality. They were marks of difference chiefly in that they were marks of differing severity. ${ }^{106}$ Treating the subject of exanthemata this way, Fernel was more traditional than some of his contemporaries. Augenius, for example, writing shortly after Fernel's death, made clear that Renaissance medical authors were both aware of the writings of Rhazes on smallpox and measles ${ }^{107}$ and had maintained a tradition based on him which acknowledged some particularity, some distinctiveness in these two diseases based, in part, on the character of the rash. ${ }^{108}$

It is not difficult to appreciate, however, that the underlying unity of fever, which was so central to classical doctrine, suggested a continuum, a gradation of seriousness, through all the sorts of Fevers, as much as it did distinctiveness and particularity. Like sweats, vomiting, diarrhoea, or buboes, rashes were efforts of the body to discharge the disease material that had been generated within. The recognition, therefore, of distinctive differences in the rashes did not stimulate special curiosity, given the theoretical framework by which they were perceived and interpreted. More than that, traditional therapy, rationalized on the basis of that same framework, did not take serious account of the differences in rashes either. Thus, the tradition of distinguishing and separately discussing smallpox and measles, as reflected in the work of Augenius,

\footnotetext{
${ }^{104}$ In general, see John D. Rolleston, The history of the acute exanthemata, The Fitzpatrick Lectures for 1935 and 1936, London, Heinemann, 1937. Despite its age, James Moore's The history of the small pox, London, 1815, is remarkably useful.

${ }^{105}$ Fernel did not refer to smallpox or measles as such, at all. He discussed exanthemata in op. cit., note 18 above, p. 187f. For a long discussion of the confusing topic, pest, pestilential Fevers, malignant Fevers, and putrid Fevers, see Sennert, op. cit., note 9 above, Bk. IV, Ch. 7.

${ }^{106}$ For examples of this approach, see Ballonius, op. cit., note 10 above, pp. 35-37, but also p. 258 . The editor of Ballonius, writing around 1636, still thought in the same way, as is revealed by his editorial comment to the first of these two passages (ibid., pp. 49-51; see also p. 202). As is true for Fernel, "variolae" appears nowhere in the extensive index to Ballonius. Similarly, see Platter, op. cit., note 7 above, pp. $47 \mathrm{f}$., 83, and the interesting case history No. XVII, pp. 344-347. In his table of Fevers at the beginning of his work, Platter did not separate the exanthemata from the general category of malignant or pestilential Fevers.

${ }^{107}$ Regarding Rhazes' views on smallpox and measles, see Augenius, op. cit., note 7 above, p. 386.

108 Ibid. The book is really composed of two parts. In the earlier work, in Bk. VI, which is on pestilential Fevers, the last $\mathrm{Ch}$. (XXII, pp. 278-281) is on the nature and causes of smallpox, measles, and petechiae. Three books (VIII, IX, and X) were added later dealing with the treatment of the symptoms of pestilential Fevers, smallpox and measles, and their treatment, respectively. In the earlier work, he pointed out that smallpox and measles differ, not in kind but only in degree (p. 279). The morphological features of the rash were discussed at length. Yet Augenius discussed these matters with respect to Fernel's views entirely as if he believed himself to be working within the same theoretical framework (even while disagreeing with Fernel). See, e.g., Bk. IX, Ch. 12, p. 382, and, regarding various contemporaries, p. 279f. That the exanthemata were distinguished from plague by the time of the Black Death is suggested by Morris, op. cit., note 95 above, p. 42. Smallpox was apparently listed separately as a cause of death in the Bills of Mortality in the last two decades before 1600 (T. R. Forbes, Chronicle from Aldgate: life and death in Shakespeare's London, New Haven, Conn., Yale University Press, 1971, pp. 100-105. See also F. P. Wilson, The plague in Shakespeare's London, Oxford University Press, 1927, pp. 118, 120f., and 123f.).
} 


\section{Thomas Willis and the fevers literature of the seventeenth century}

could be regarded within the classical tradition as more academically satisfying than as practically desirable. ${ }^{109}$

By Willis's time, this situation had not really changed. The conceptual framework within which Willis and his contemporaries thought about the phenomena of Fevers and their treatment was not really any more conducive to thinking about rashes as signs of distinctive diseases than it had been for Fernel. ${ }^{110} \mathrm{Or}$, to express it another way, the inclinations of a Willis, as of a Fernel, to seek a rational explanation of rashes in terms of their common function - expulsion of the disease matter - outweighed any empirical tendency to accept as significant, even though unexplained, the morphological or anatomical distinctiveness of rashes, a tendency which would only arise subsequently. ${ }^{111}$

Yet, despite this theoretical environment, I would argue that seventeenth-century authors increasingly came to write about smallpox and measles as if they were distinct diseases. Though followers of Fernel and the classical tradition in this regard can still be found in the later seventeenth century; the leading writers and the main line of development follow authors like Augenius in devoting at least one separate chapter to smallpox and measles. ${ }^{112}$

Obviously more study is needed of the way in which the exanthemata were handled in the Fevers literature of the sixteenth and seventeenth centuries before we can be certain that there really was such a transition, and if so, of the precise form it took and the circumstances surrounding it. Even if it can be convincingly documented, there could be several reasons for the change, as has been suggested. But, in reflecting on this, two things are of interest. First, contemporary authors were themselves divided on the question of whether or not there was evidence of smallpox in ancient literature, a lack of which was grounds for discrediting that literature's relevance to their own time. ${ }^{113}$ Second, the evidence, upon which we still depend, that smallpox increased in

\footnotetext{
${ }^{109}$ Bauderon, op. cit., note 14 above, despite three chapters on the particular forms of malignant Fevers, has nothing on the exanthemata. The point is not that the distinctions among exanthemata were not noticed but that theory argued against their significance as evidence of difference.

110 For the persistence of this tradition in early Restoration England, see ibid., and Pyretologia, op. cit., note 61 above, $\mathrm{Ch} .10$.

111 Categorical statements plus empirical arguments for the view that smallpox and measles are different in kind and not just in degree were made by Thomas Fuller, Exanthematologia: or an attempt to give a rational account of eruptive Fevers, especially of the measles and small-pox, London, 1730, p. 141. He also argued that these diseases were to be dissociated from all other diseases and thought of as a distinct class, the "exanthemata" (p. 259f.) It seems reasonably clear that the practice of variolation in the eighteenth century also helped to clarify matters.

112 Most notably, of course, Sennert, op. cit., note 9 above, $\mathrm{Ch}$. 10. He began discussing the exanthemata generally, p. 833. In a notice of Sydenham's first work on Fevers (1666), the reviewer said, "in the Fourth Section, the author, in conformity to the custom of those that write of fevers, discourses of the smallpox; ..." (quoted in The works of Thomas Sydenham, ed. and trans. by R. G. Latham, London, Sydenham Society, vol. 1, 1848, p. XXIX). It is a curious fact that while Van Helmont stressed the "thingliness" of diseases, he did not contribute to the classificatory possibilities of his ontology. My impression is that he combined an extreme individuation of disease with, at times, a universality in the term "Fever" and even in treatment. At least see passages from his Opuscula medica inaudita, trans. J. C[handler], London, 1662, p. 987 , sec. 7 ; p. 1005, sec. 16; p. 1007, sec. 5 ; p. 1009, sec. 9; and p. 1010, sec. 12, where he casually refers to the common names of Fevers but in a jumbled and perfunctory way. However, see also p. 940, sec. 8, p. 947 , sec. 11 , and $\mathrm{Ch}$. VI.

${ }^{113}$ See Lloyd Stevenson, "“New diseases" in the seventeenth century', Bull. Hist. Med., 1965, 39: 1-21. The general notion that diseases had changed so that traditional medicine was no longer relevant was
} 
these two centuries arises from the Fevers literature and so can hardly be used to argue that a changed disease situation was affecting the trends in that literature. More historical epidemiology of smallpox before 1700 is needed. ${ }^{114}$

Going further out on the speculative limb, one might argue that this period was truly momentous in the evolution of our knowledge of Fevers, and that it was so just because of the shifting patterns of disease. The striking prominence of plague and the accumulated experience with it over several centuries seems to have helped to downgrade the theoretical connexion it was supposed to have, through the notion of malignity, with other continued Fevers, on the one hand, and with the exanthemata, on the other. ${ }^{115}$ Combined with increasing regard for the empirically established distinctiveness of the exanthemata, this would have done much to isolate the major continued Fevers as a separate group. ${ }^{116}$ Then, to push the argument further, with the gradual recession of intermittent Fevers in the eighteenth century, another boundary line around the continued Fevers would have been drawn. This in turn would have set the stage for the last problem to be solved, differentiation within the group of continued Fevers, in the eighteenth and nineteenth centuries. ${ }^{117}$

another subversive potential of Paracelsian and Helmontian thought, and clearly used for its social leverage. See Pagel, op. cit., note 40 above, p. 139; Rattansi, op. cit., note 78 above, p. 20; Noah Biggs, Mataeotechnia medicinae praxis. The vanity of the craft of physick, London, 1651; and Nedham, op. cit., note 77 above, title-page and p. 31. With specific references to smallpox, see ibid., p. 53f. Sydenham, probably for quite different reasons, argued likewise, op. cit., note 3 above, $V: 4: 14$. A more conservative view was that smallpox was known to the ancients but merely subsumed under exanthemata and ecthymata (Hactenus inaudita, or animadversions upon the new found way of curing the smallpox, London, 1663, p. 23), or that, whatever its earlier history, it had grown from a mild into a very serious disease (T[obias] Whitaker. An elenchus of opinions concerning the cure of the smallpox, London, 1661, epistle to the reader, Pyretologia, op. cit., note 61 above, p. 246).

114 The chief source for the view that smallpox only became epidemic in England after 1600 seems to be Creighton, op. cit., note 97 above, vol. 1, 1891, pp. 463-467; vol. 2, 1894, pp. 434-443. But Creighton's sources were the Fevers literature such as is being evaluated here. E. W. Goodall disagreed with Creighton ( $A$ short history of the epidemic infectious diseases, London, John Boyle, 1934, p. 55). Thought in Europe would possibly have been influenced by the devastating effects of smallpox among natives in the new world. See Alfred W. Crosby Jr., The Columbian exchange: biological and cultural consequences of 1492, Westport, Conn., Greenwood Press, 1972, Ch. 2. For a detailed and interesting comparison of the seventeenth with the eighteenth century, based on Bills of Mortality, see W. A. Guy, 'Two hundred and fifty years of small pox in London', J. Statist. Soc., 1882, 45: 399-443.

115 Sydenham was obviously wrestling with this. See my 'Thomas Sydenham: the development of his thought, 1666-1676', Ph.D. dissertation, Baltimore, Md., The Johns Hopkins University, 1975, pp. 26-29. It would be very helpful to discover whether or not there is any discernible trend in the seventeenth century to get plague theoretically, as well as practically, distinct from pestilential and malignant Fevers. My own impression is that it remains equivocal and problematic. Such studies would help historical epidemiologists in their discussions over the likelihood that plague was clearly distinguished by contemporaries. See Morris, op. cit., note 95 above, p. 41 f. and The plague reconsidered ..., op. cit., note 96 above, p. $18 f$. Slack has argued that the changing epidemic pattern of plague over the sixteenth and seventeenth centuries could have led to "the growing habit of distinguishing plague from other diseases" (Slack, in Webster, (1979), op. cit., note 96 above, pp. 50-55).

116 However, another source of confusion would have been the petechial rash of typhus, said to be present in 97.7 per cent of cases (Charles Murchison, $A$ treatise on the continued fevers of Great Britain, ed. W. Cayley, 3rd ed. London, 1884, p. 131f.). Another concept which died hard, constitutionalism, tended to group together, at least theoretically, all cases that occurred during some seasonally swelling tide of febrile illnesses. See, for example, Willis, op. cit., note 29 above, pp. 648f., 653, 663f., where this seems to be at work. Only a receding tide of endemic diseases with more sharply defined waves of single diseases would help to dissuade one of such an orientation.

${ }^{117}$ For which see Murchison, op. cit., note 116 above. 


\section{Thomas Willis and the fevers literature of the seventeenth century}

It is unlikely that the real story is anything like as simple, or, indeed, that we may ever be able to account for the changes satisfactorily. But the above can serve as an illustration of how the changing disease environment may have played a major role in the development of thought about Fevers.

The chief purpose of this highly selective look at the seventeenth-century Fevers literature has been to suggest its richness and promise for further study. In particular, a case study of Thomas Willis's De febribus has been used to demonstrate how intellectual, social, and natural events all contributed to the character of such a literature and how all these perspectives offer scope for more research.

Although this literature reflects no mere dialectic of ideas, nor a simple interaction between ideas and observations or experiments, it does bear some relationship to contemporary science. Both Fernel and Willis, and many others in between, were "scientists" or at least natural philosophers within the context of their respective periods, and their interest in Fevers, whatever else it might have been, was certainly philosophical.

Yet, in the context of the seventeenth century, Fevers as natural events or objects of study were somehow different even from things like normal human form and function, let alone plants and animals, matter and motion. Obviously Fevers did not lend themselves to experimentation in humans, and animal analogues do not seem to have been thought of, or even possible. Since the classical tradition of Fevers, as preeminently physiological diseases, survived translation into a modern idiom, morbid anatomy did not seem a promising avenue, ${ }^{118}$ although clinical description, Baconian fashion, was gaining credence and would come to full flower in Sydenham's magnum opus, months after Willis died. ${ }^{119}$ Still constructed, then, out of philosophical speculation and commentary, long after subjects like anatomy and physiology had begun to utilize descriptive science and laboratory experimentation, the Fevers literature reflected, rather than engendered, changing beliefs about the nature of nature.

But this is no reason for ignoring its intellectual genealogy, its technical meanings, undeclared assumptions, sense of problem, connecting links, and intellectual trends. Its very uniqueness and special character as a genre of literature make it worthy of study. It reflected not a failed scientific effort but a living medical tradition with its own part to play in an evolving society.

In the period in question, Fevers were the very essence of a medical, not a scientific subject. They could not easily be abstracted from the context of historical contingencies and human affairs. They were striking events, not just to be watched like the beat of the heart or the movement of the stars, but to be reacted to like the natural disasters they were. They demanded not just to be understood but to be overcome. To those who had a vested interest in the rational order of society (as they defined it), the need to act entailed the need to know, and the claim to know promoted the claim to govern action. But, in seventeenth-century England at least, neither medical

\footnotetext{
118 And many Helmontians were even opposed to any anatomy as irrelevant to the knowledge needed to treat Fevers.

${ }^{119}$ Sydenham, op. cit., note 3 above, preface to the 3 rd ed., sect. 5.
} 


\section{Don G. Bates}

knowledge nor medical governance had a solid base. If treatises on Fevers were ever written without social purpose, they were rarely read as such. Philosophical discourse became the currency of social polemic and ideas sometimes got exchanged in the social and political arena with more concern for what they would support than why they had been minted.

Given its philosophical integrity and its generation out of the interaction of men with the past, it would be a mistake to regard the Fevers literature as a mere epiphenomenon, a secretion from the organs of social metabolism. Nevertheless, it does represent a rich corpus of social testimony, the offspring also of the obligatory interaction of men with men and men with nature. If that literature is going to be fully appreciated, a similar interaction of intellectual with social history is required.

Finally, it has been argued that this literature was not the product of systematic investigative science. On the other hand, we cannot dismiss the very real possibility that it was materially influenced by accumulated and changing experience with the disease environment. The satisfactory establishment of links between the two may prove difficult, but the result may well be worth the effort.

It is interesting to reflect on the possibility that all the major Fevers that afflicted Europe and North America were sorted out almost entirely before the rise of bacteriology. ${ }^{120}$ Nor did advances in anatomy and physiology from Vesalius and Harvey to Claude Bernard play any significant part. Starting from the Greeks and the Arabs, practically all the progress that was made was accomplished clinically and socially until the help of morbid anatomy was added in the early nineteenth century. ${ }^{\mathbf{1 2 1}}$ Through all that time, the impact of experience, while at times confusing, must nevertheless have been of considerable significance. But precisely how and when remains to be established. The period under study looks promising in this regard.

There has been a tendency to use the Fevers literature of the seventeenth century as a quarry which intellectual, social, and epidemiological historians have mined selectively for the materials they have needed to build their particular arguments. But this has sometimes meant, as with Willis's De febribus, that the same treatise has been used for such disparate purposes that its integrity has been ignored. The assumption upon which this paper has been written is that there is a justification, even a need, to examine the literature on Fevers as an integral whole. Part of its unity arises from the tradition to which it remained remarkably faithful in important ways. The other source is the subject to which it addressed itself - Fevers - a set of conditions and events which were cohesive and almost unique as a category of natural phenomena. The fragmentation which the literature suffered, at the hands of social polemic, obscures but does not destroy that essential unity. Indeed, a knowledge of the original unity can illuminate the process of fragmentation, providing a deeper insight into the social purposes it was being made to serve. Mediating as it does among a number of special intellectual, social, and natural forces, the Fevers literature of the seventeenth century provides a challenge to historians which is almost unique.

\footnotetext{
${ }^{120}$ Apart from adding precision to diagnosis in particular cases, surely the first contributions of bacteriology were uncovering modes of spread, developing vaccines and antitoxins, and establishing a laboratory basis for the study of infectious diseases.

${ }^{121}$ Conceivably the use of cinchona, inoculation, and then vaccination, played a part.
} 